\title{
Mixed linage kinase 3 functions as a cGMP- dependent protein kinase I alpha substrate and regulates blood pressure and cardiac remodeling in vivo
}

\author{
Timothy Calamaras ${ }^{1}$, Robert Baumgartner ${ }^{1}$, Guang-rong Wang ${ }^{1}$, Roger Davis², Mark Aronovitz ${ }^{1}$, David Kass ${ }^{3}$, \\ R Karas ${ }^{1}$, Robert M. Blanton ${ }^{1 *}$
}

From 7th International Conference on cGMP Generators, Effectors and Therapeutic Implications Trier, Germany. 19-21 June 2015

Protein kinase G I alpha (PKGI $\alpha$ ) counteracts hypertension and pathologic cardiac remodeling. These effects require the PKGI $\alpha$ leucine zipper (LZ) protein binding domain. However, PKGI $\alpha$ LZ-binding substrates mediating these effects remain incompletely understood. We previously demonstrated that Mixed Lineage Kinase 3 (MLK3) binds the PKGI $\alpha$ LZ domain in the heart. In the present study we hypothesized that MLK3 functions as a PKGIa substrate and cardiovascular effector.

We observed that recombinant MLK3 precipitated with affinity purified PKGI $\alpha$ but not with LZ mutant PKGI . When PKGI $\alpha$ was precipitated with RP-cGMP beads, which inhibit PKG kinase activity, we observed decreased PKGI $\alpha$-MLK3 co-precipitation, supporting a requirement of PKGI $\alpha$ kinase activity for MLK3-PKGIa interaction. PKGI $\alpha$ phosphorylated MLK3 in vitro as assayed by Western blot.

We next analysed mice with genetic deletion of MLK3. In the baseline state, $\mathrm{MLK3}^{-1-}$ mice display normal cardiac function as assessed by echocardiography and invasive cardiac hemodynamics. MLK $3^{-/-}$mice develop cardiac hypertrophy by 3 months of age (heart weight/ tibia length $64.4 \pm 1.9 \mathrm{mg} / \mathrm{cm} \mathrm{WT}, 73.6 \pm 2.1 \mathrm{mg} / \mathrm{cm}$ $\mathrm{MLK3}^{-1-} ; \mathrm{p}<0.001 ; \mathrm{n}=11 \mathrm{WT}, 14$ MLK3-/-). Compared with WT littermates, anesthetized $\mathrm{MLK}^{-1-}$ mice have elevated blood pressure (BP) $(94.3 \pm 2.1 \mathrm{mmHg}$ WT, $\left.109.3 \pm 2.5 \mathrm{mmHg} \mathrm{MLK3}^{-/-} ; \mathrm{p}<0.001\right)$. Conscious male $\mathrm{MLK3}^{-1-}$ mice monitored continuously with implantable

\footnotetext{
* Correspondence: rblanton@tuftsmedicalcenter.org

'Molecular Cardiology Research Institute, Tufts Medical Center, Boston, Massachusetts 02111, USA

Full list of author information is available at the end of the article
}

arterial radiotelemetry (10-12 weeks of age) had overt hypertension compared with WT littermates (Systolic BP: WT $121.5 \pm 2.0 \mathrm{mmHg}, \mathrm{MLK}^{-/-} 161.6 \pm 5.1 \mathrm{mmHg}$; $\mathrm{p}<0.01$; Diastolic BP: WT $87.0 \pm 2.9 \mathrm{mmHg}, \mathrm{MLK}^{-1-}$ $114.5 \pm 2.7 \mathrm{mmHg} ; \mathrm{p}<0.001 ; \mathrm{n}=4 \mathrm{WT}, 3 \mathrm{MLK}^{-/-}$). We observed no difference in baseline heart rate between genotypes.

Chronic administration of hydralazine $(250 \mathrm{mg} / \mathrm{L})$ normalized BP in $\mathrm{MLK} 3^{-/-}$mice, but did not completely inhibit cardiac hypertrophy. Further, in response to LV pressure overload by transaortic constriction (TAC), which equalized left ventricular (LV) systolic pressure between genotypes, $\mathrm{MLK}^{-1-}$ mice had increased LV hypertrophy (LV/Tibia length) as well as elevated LV end diastolic pressure, and worsening of LV ejection fraction, preload recruitable stroke work, and other LV systolic and diastolic indices $(\mathrm{n}=8-10)$, indicating advanced cardiac dysfunction.

Together, our findings identify MLK3 as a direct PKGI substrate, and reveal that deletion of MLK3 leads to hypertension and pathologic cardiac hypertrophy. These findings support a model in which, in response to activation by PKGI $\alpha$, MLK3 inhibits hypertension and cardiac hypertrophy. We conclude that identifying novel PKGI L LZ substrates, like MLK3, may reveal new candidate therapeutic targets for hypertension and heart failure.

\footnotetext{
Authors' details

${ }^{1}$ Molecular Cardiology Research Institute, Tufts Medical Center, Boston, Massachusetts 02111, USA. ${ }^{2}$ Program in Molecular Medicine, University of Massachusetts Medical School, Worcester, Massachusetts 01605, USA.
} 
${ }^{3}$ Department of Cardiology, Johns Hopkins Medical Institutions, Baltimore, Maryland 21205, USA.

Published: 2 September 2015

doi:10.1186/2050-6511-16-S1-A24

Cite this article as: Calamaras et al: Mixed linage kinase 3 functions as a cGMP-dependent protein kinase I alpha substrate and regulates blood pressure and cardiac remodeling in vivo. BMC Pharmacology and

Toxicology 2015 16(Suppl 1):A24.

Submit your next manuscript to BioMed Central and take full advantage of:

- Convenient online submission

- Thorough peer review

- No space constraints or color figure charges

- Immediate publication on acceptance

- Inclusion in PubMed, CAS, Scopus and Google Scholar

- Research which is freely available for redistribution

Submit your manuscript at www.biomedcentral.com/submit
C Biomed Central 